\title{
Development of Scientific and Technical Solutions to Create Hybrid Power Source Based on Solid Oxide Fuel Cells and Power Storage System for Responsible Consumers
}

\author{
A.I. Chivenkov, E.V. Kryukov, A.B. Loskutov and E.N. Sosnina
}

\begin{abstract}
This article deals with hybrid power source (HPS) based on solid oxide fuel cells (SOFC) developed by the authors. HPS includes generating, power storage, integration, and active-adaptive control systems. Generating system includes modular electrochemical generator based on SOFC and reformer. Power storage system consists of capacitive storage and accumulation batteries. Accumulation batteries are created of alkaline nickel-cadmium batteries with improved energy characteristics. The base of integration system is current distribution converter. For the active-adaptive control system realization, the algorithm of HPS functioning has been designed. The conducted research of HPS experimental prototype characteristics allowed to confirm the efficiency of scientific and technical solutions.
\end{abstract}

Keywords Smart hybrid power source - Solid oxide fuel cell $\cdot$ Capacitive storage Nickel-Cadmium battery $\cdot$ Actively adaptive control system

\footnotetext{
A.I. Chivenkov $(\bowtie) \cdot$ E.V. Kryukov · E.N. Sosnina

Nizhny Novgorod State Technical University n.a. R.E. Alekseev,

Nizhny Novgorod, Russia

e-mail: chyvenkov@mail.ru

E.V. Kryukov

e-mail: e.kryukov@rambler.ru

E.N. Sosnina

e-mail: sosnina@nntu.nnov.ru
}

A.B. Loskutov

Head of Department, Nizhny Novgorod State Technical University

n.a. R.E. Alekseev, Nizhny Novgorod, Russia

e-mail: loskutov@nntu.nnov.ru 


\section{Introduction}

A great attention of different international scientific groups is paid to the development of power installations (PI) based on fuel cells (FC) and their application in power supply systems [1, 2]. Japanese, American, and German scientists have achieved significant success in this research. Thus, German company Siemens Westinghouse developed and tested PI with power from 5 to $300 \mathrm{~kW}$ [3]. Company General Electric tested compact electrochemical generator with power from 1 to $6 \mathrm{~kW}$ [4]. Company Cummins-SOFCo developed PI based on FC pilot prototype with power $1 \mathrm{~kW}$, which had continuously worked for $2000 \mathrm{~h}$ using natural gas [5].

The operation of the FC is based on the principle of direct conversion of chemical into electrical energy [6]. The main advantages of FC installations are high efficiency that can reach $85 \%$ considering heat recovery, and environmental friendliness. Due to the lack of direct fuel chemical contact with the oxidant, the amount of harmful emissions is almost 100 times less when compared with conventional power installations [7].

However, widespread application of FC in power supply systems is constrained by a number of problems [8]. There is high cost of PI based on FC due to the complexity of its manufacturing technology and the high cost of the materials and high temperature of FC operation, whereby it takes a long time to start the PI and to achieve the optimum operating condition. Low FC maneuverability makes use of this PI inefficient at the irregular daily schedule of electric group load of consumers.

The problem of improving FC efficiency can be resolved by applying them with other energy sources. One of solutions to this problem is to create a hybrid power source (HPS) on the basis of fuel cells and power storage system. The experimental prototype of such a source is developed at the Nizhny Novgorod State Technical University n.a. R.E. Alekseev (NNSTU) [9]. Solid oxide fuel cells (SOFC) are used as the main energy source; accumulation batteries (AB) are used as an additional energy source and capacitive storage (CS) is applied to cover peak loads.

This approach is used by other researchers [10]. The novelty of the suggested solution is that developed HPS allows to realize active-adaptive PI modes changing with the constant generating power of electrochemical generator based on SOFC and dynamic changing of load power which had not been considered before. Developed PI has improved maneuverability, reduced fuel consumption, and increased service life of SOFC.

This article contains scientific and technical solutions to develop of HPS based on SOFC and HPS prototype research results.

\section{Scientific and Technical Solutions to Hybrid Power Source Development}

Developed HPS includes generating system, power storage system, integration system and an active- adaptive control system [11]. 
Generating system with electrochemical generator based on SOFC provides a continuous operation of HPS in basic part of schedule of consumers electrical load. Electrochemical generator has modular execution. High temperature parts are combined in one block: SOFC stack, reformer, afterburning-heating system. SOFC stack consists of planar elements. Reformer is a matrix convertor with high efficiency of hydrocarbon conversion into synthesis gas.

Power storage system consists of capacitive storage and accumulation batteries (AB). If the load decreases lower specified value the electrical energy accumulation from the network happens in $\mathrm{AB}$. In case of load excess of given power, $\mathrm{AB}$ gives stored electrical energy into the network. Capacitive storage is used for peak load supply.

The realization of $\mathrm{AB}$ is done based on nickel-cadmium accumulators with sintered-type electrodes (sintered-type NCA). This type of accumulators is produced by the German company « Hoppecke » and used by high-speed trains in Russia [12]. However, producing such an accumulators complicated technological operations are applied that is why $\mathrm{AB}$ are very expensive. The technology of sintered-type NCA producing is developed by NNSTU scientists which let us to reduce electrodes cost saving high specific electrical characteristics and make the manufacturing more ecological friendly. The specific cost of such an accumulators is 1.5-2 times lower than analogs with the same energetic characteristics able to work in wide range of charge and discharge current densities and temperatures.

The producing technology of positive electrode does not contain chemical metallization, the negative electrode is made by pressing and does not contain metalized foundation. Such technologies are not used nowadays.

Integration system provides generating and power storage systems connection and HPS currents redistribution. The HPS integration system basis is current distribution converter (CDC) between its elements [13]. Schematic diagram of the $\mathrm{CDC}$, developed by the authors, is shown in Fig. 1.

CDC includes three DC/DC upconverters. DC/DC converter 1 converts the voltage of $50 \mathrm{~V}$ generated by SOFC to $400 \mathrm{~V}$, that is rated for the load and the capacitive storage, DC/DC converter 2 to voltage of $100 \mathrm{~V}$, that is, operating

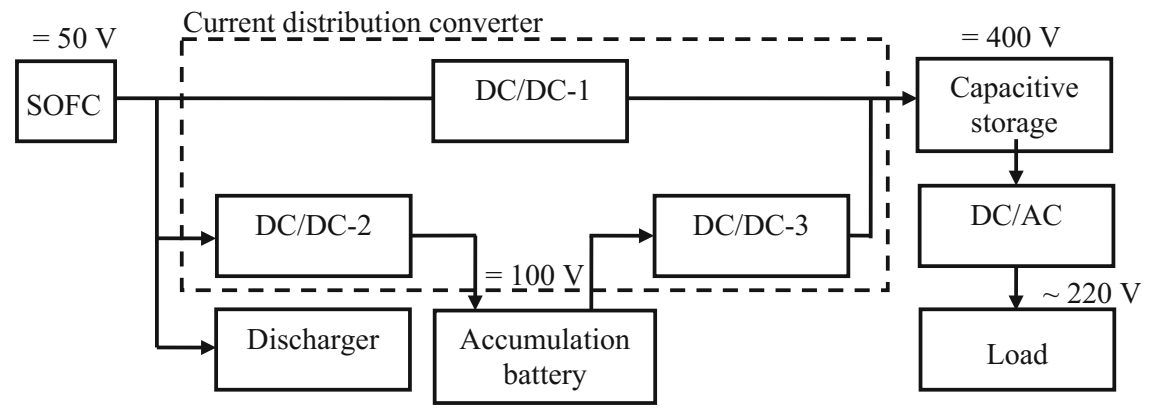

Fig. 1 Schematic diagram of current distribution converter 
voltage for the accumulation batteries. $\mathrm{DC} / \mathrm{DC}$ converter 3 is used for $\mathrm{AB}$ and capacitive storage voltage matching.

Active-adaptive control system realizes monitoring of HPS and load electrical parameters and also regulating and control of current distribution between the HPS elements and load depending on consumers power. Control system works according to algorithm which is shown in Fig. 2.

HPS experimental prototype has created for verification of developed solutions efficiency.

The basic criterion of the algorithm is to maintain the voltage on the capacitors in a predetermined range (minimum- $350 \mathrm{~V}$, maximum- $450 \mathrm{~V}$ ). The minimum level of voltage matches the ability to ensure the efficiency of the DC/AC inverterstabilization of the output AC voltage of $220 \mathrm{~V}, 50 \mathrm{~Hz}$, and the implementation of consumers power supply in the power range from 0 to nominal value.

Under the condition of constant power generation and load, the regulation of the current $\mathrm{AB}$ values and capacitors is carried out at the expense of the three structural elements: DC/DC converter 1, DC/DC converter 3 and $\mathrm{AB}$ state diagnostic unit.

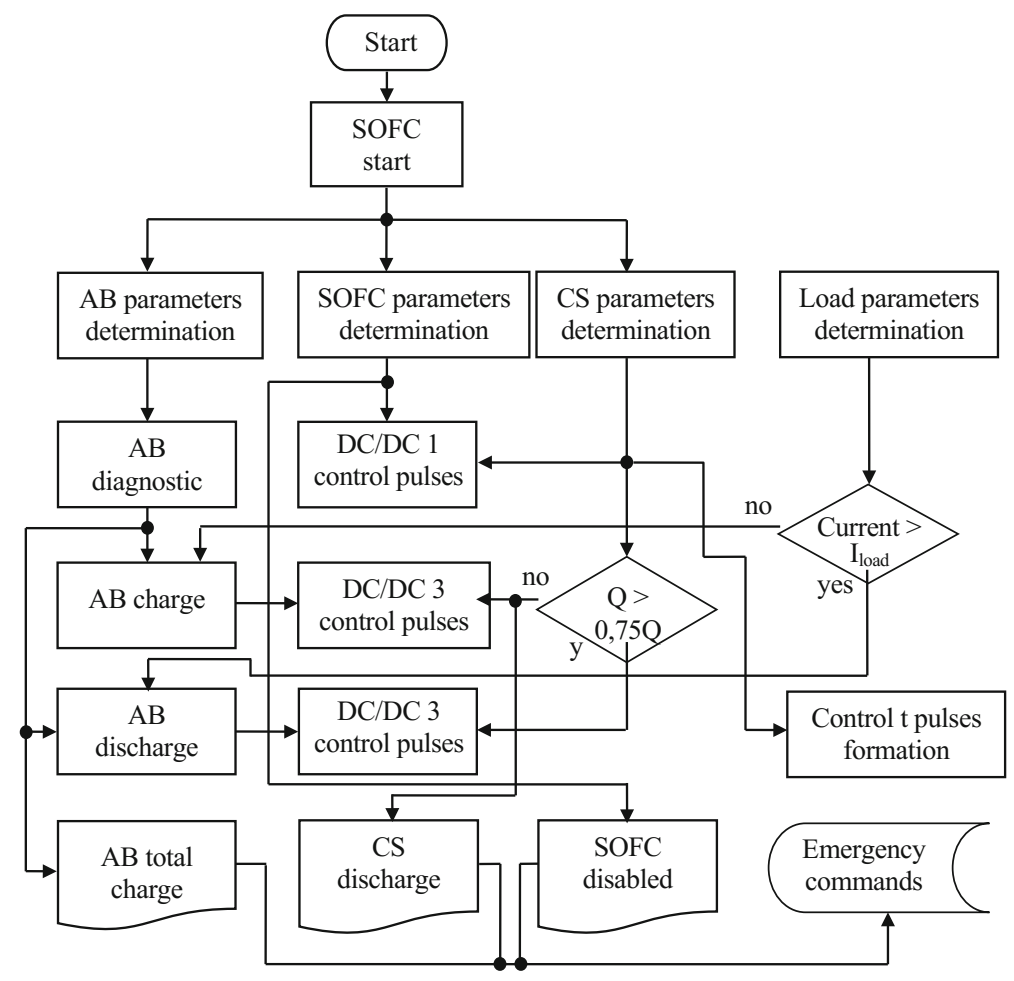

Fig. 2 An algorithm of the HPS operation 


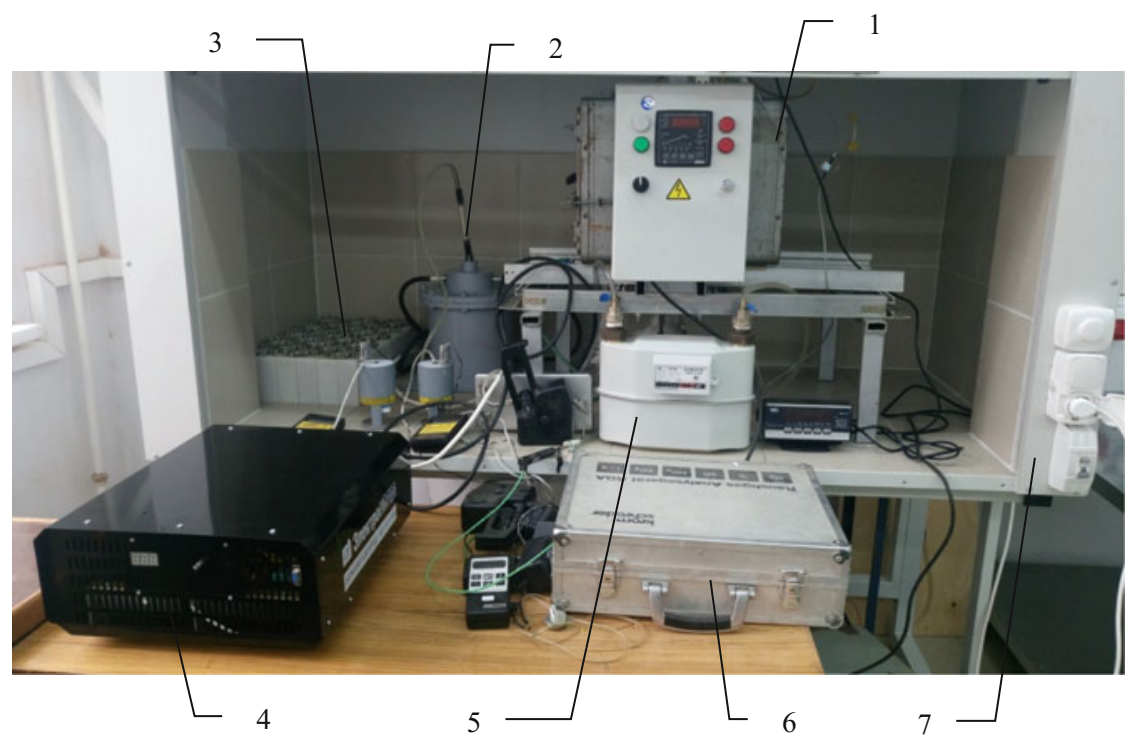

1 - thermobox with SOFC stack; 2 - matrix converter; 3 - NCA battery; 4 - current distribution converter; 5 -gas flow meter; 6 - gas analyzer; 7 - fume hood

Fig. 3 HPS experimental prototype

\section{Hybrid Power Source Experimental Prototype}

Experimental prototype includes four modules: generation system module, power storage system module, current distribution converter, and active-adaptive control system. HPS experimental prototype photo is shown in Fig. 3.

Maximum HPS experimental prototype output power is $1 / 5 \mathrm{kVA}$, output voltage $-220 \mathrm{~V}, 50 \mathrm{~Hz}$.

Following tests have conducted on experimental prototype: electrochemical generator electrical characteristics tests; NCA battery charge and discharge characteristics test; current distribution converter electrical characteristics tests.

\section{Results and Discussion}

\section{Generating system research}

Electrochemical generator electrical characteristics research has been conducted with hydrogen consumption $4 \mathrm{l} / \mathrm{min}$ and air consumption $15 \mathrm{l} / \mathrm{min}$. Research results 
are presented in Table 1. Experimental electrochemical generator volt-ampere and watt-ampere characteristics are shown in Fig. 4.

The results showed that there is significant drop of voltage with the working time less than $10000 \mathrm{~h}$.

Assessment of emergency developing possibility while the PI is working has been conducted during the research. Theoretical analysis and experimental research results showed that HPS start and stop are the most dangerous modes. During start, heating speed exceeding may cause uneven heating and destruction of the element. The similar situation is possible when cooling.

\section{Power storage system research}

NCA charge and discharge characteristics experimental research has conducted. The time dependencies of current and voltage were obtained at different charge and discharge modes. The results are shown in Figs. 5, 6, 7, and 8.

The results analysis showed that the discharge time is about $6 \mathrm{~h}$ with current 2.5 A (Fig. 5). Battery voltage is stable for about $5.5 \mathrm{~h}$, there is its rapid decline in the last half hour. The NCA average discharge voltage is $14.0-14.5 \mathrm{~V}$.

Table 1 Electrochemical generator research results with hydrogen consumption 4 1/min and air consumption $15 \mathrm{l} / \mathrm{min}$

\begin{tabular}{c|c|l|l}
\hline Output power, W & Output voltage, V & Output current, A & Temperature, ${ }^{\circ} \mathrm{C}$ \\
\hline 86 & 26 & 3,31 & 750 \\
\hline 185 & 24,5 & 7,55 & 748 \\
\hline 340 & 20,2 & 16,83 & 749 \\
\hline 514 & 16 & 32,13 & 748 \\
\hline
\end{tabular}

Fig. 4 Experimental electrochemical generator volt-ampere and watt-ampere characteristics $1,2-$ characteristics after series of experiments, 3, 4-original characteristics

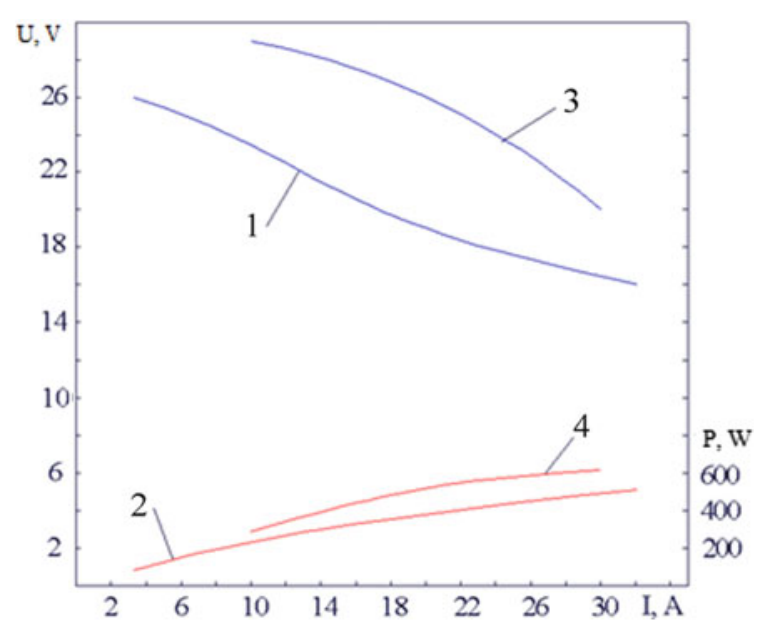

1, 2 - characteristics after series of experiments, 3, 4-original characteristics 
Fig. 5 NCA discharge voltage changing with discharge current $2.5 \mathrm{~A}$

Fig. 6 NCA discharge voltage changing with discharge current $20.0 \mathrm{~A}$
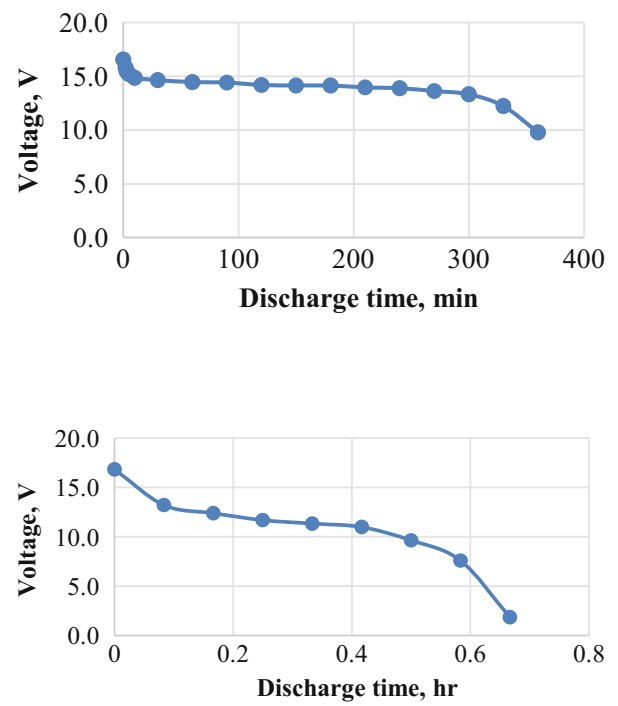

Fig. 7 NCA charge voltage changing with charge current $2.5 \mathrm{~A}$

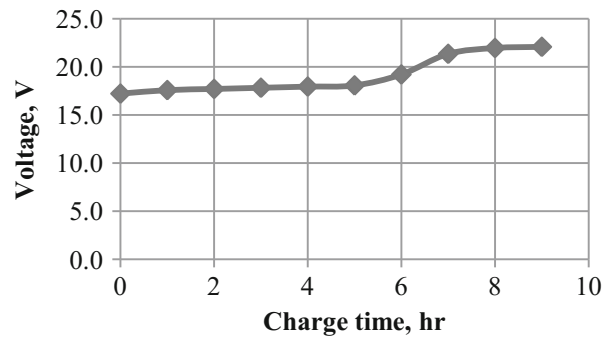

Fig. 8 NCA charge current changing with charge voltage $19.5 \mathrm{~V}$

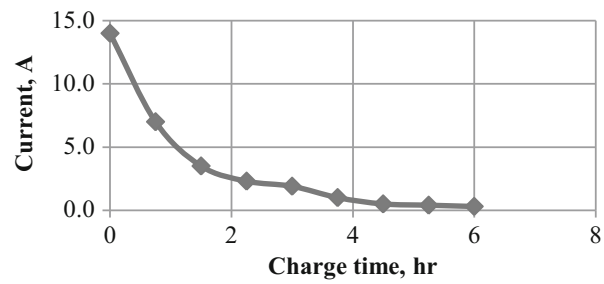

Increase of the discharge current reduces the discharge time to eight times. The dynamics of the operating voltage during $\mathrm{AB}$ discharge with discharge current 20.0 A is shown in Fig. 6.

To provide NCA high discharge characteristics, its charge can be carried out in two ways: either by constant current or by constant voltage.

The charge at a 2.5 A constant current was carried out to $120 \%$ of rated capacity. $\mathrm{AB}$ charging curve can be divided into two sections (Fig. 7). Initially, main 
reactions are the formation of higher oxides of nickel in the positive electrode and the metal cadmium in the negative when the $\mathrm{AB}$ voltage is 16.5-18.0 V. Further significant increase of voltage is due to the occurrence of oxygen liberation side reactions of nickel oxide electrode and hydrogen on the cadmium electrode. The final discharge $\mathrm{AB}$ voltage is up to $22.0 \mathrm{~V}$ at chosen charge mode. Charge time is 8-10 h.

The charge of the battery can be accelerated by applying a constant voltage mode. The charge carried out with voltage $19.5 \mathrm{~V}$.

At the initial period of the charge, current can reach values of 13.0-15.0 A (Fig. 8). Then there is its rapid reduction. After $1.5 \mathrm{~h}$ there is some stabilization of the current, but after $3 \mathrm{~h}$ the amount of current is reduced again and it is stabilized at the level of $0.2-0.3 \mathrm{~A}$. Charge time is $4-5 \mathrm{~h}$.

Results analysis showed that DC source output power should be not less than $50.0 \mathrm{~W}$ when charging by a constant current. Battery charge by constant voltage requires the use of semiconductor devices with an output power of up to 300.0 $500.0 \mathrm{~W}$.

\section{Integration system research}

DC/DC-1, DC/DC-2 и DC/DC-3 converters as part of HPS current distribution converter electrical characteristics research was conducted. Results are shown in Table 2.

Table 2 Converters electrical characteristics research results

\begin{tabular}{|c|c|c|c|c|}
\hline № & Input voltage, $\mathrm{V}$ & Input current, A & Output voltage, V & Active load, W \\
\hline \multicolumn{5}{|c|}{ DC/DC-1 } \\
\hline 1 & 50 & 4,9 & 406 & \multirow[t]{2}{*}{120} \\
\hline 2 & 80 & 3,8 & 402 & \\
\hline 3 & 50 & 19,4 & 394 & \multirow[t]{2}{*}{860} \\
\hline 4 & 80 & 14 & 394 & \\
\hline 5 & 50 & 34,4 & 390 & \multirow[t]{2}{*}{1680} \\
\hline 6 & 80 & 22 & 394 & \\
\hline \multicolumn{5}{|c|}{ DC/DC-2 } \\
\hline 1 & 50 & 2,4 & 100 & \multirow[t]{2}{*}{60} \\
\hline 2 & 80 & 2,2 & 100,5 & \\
\hline 3 & 50 & 6,2 & 99 & \multirow[t]{2}{*}{220} \\
\hline 4 & 80 & 4,9 & 99 & \\
\hline 5 & 50 & 2,4 & 105 & \multirow[t]{2}{*}{-} \\
\hline 6 & 80 & 2,4 & 106 & \\
\hline \multicolumn{5}{|c|}{ DC/DC-3 } \\
\hline 1 & \multirow[t]{3}{*}{100} & 3,5 & 402 & 120 \\
\hline 2 & & 10,6 & 397 & 860 \\
\hline 3 & & 18,5 & 397 & 1680 \\
\hline
\end{tabular}



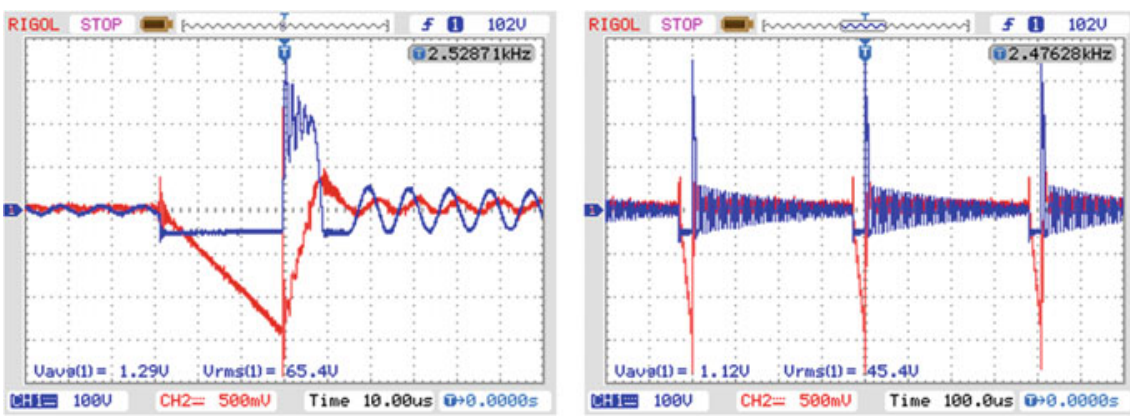

Fig. 9 DC/DC Converter 1power transistor voltage (blue line) and the resistive current sensor voltage (red line). $50 \mathrm{~V}$ input voltage and $120 \mathrm{~W}$ load power

As an example, Fig. 9 shows the waveforms of voltages at the power transistor of the DC/DC Converter 1 and the resistive current sensor with the input voltage of $50 \mathrm{~V}$ and load power $120 \mathrm{~W}$.

Result's analyses showed that when input voltage changes the transistor open state time and the transistor closed state time also changes (converter frequency). The transistor open state time for DC/DC-1, DC/DC-3 at $50 \mathrm{~V}$ is $28 \mu \mathrm{s}$, closed state $-400 \mu \mathrm{s}$, at $80 \mathrm{~V}-18$ and $430 \mu \mathrm{s}$, at $100 \mathrm{~V}-14$ and $480 \mu \mathrm{s}$.

When load changes the transistor closed state time changes (converter frequency), transistor open state time is almost unchanged.

\section{Conclusions}

Conducted HPS experimental prototype research allowed to prove the efficiency and effectiveness of developed scientific and technical solutions.

The accepted solutions allow to stabilize the SOFC generated power under varying schedule of the consumer electric load. This mode increases the duration of the SOFC operation at maximum utilization rate (energy consumption per generated power unit).

Developed HPS may be implemented as a mobile version, and stationary. Mobile version is designed to cover the deficit of electric energy in areas with rapidly developing infrastructure and load capacity exceeding the capacity of existing power networks. Stationary HPS based on SOFC and storage system would provide reliable and qualitative power supply for remote consumers of electrical energy.Research is carried out with the financial support of the state represented by the Ministry of Education and Science of the Russian Federation. Agreement no. 14.577.21.0073 05.Jun 2014. Unique project Identifier: RFMEFI57714X0073. 


\section{References}

1. Korovin N.V.: Fuel cells and electrochemical power plants. Power Engineering Institute publishing house, Moscow (2005). $280 \mathrm{p}$

2. Laosiripojanaa, N., Wiyaratnb, W., Kiatkittipongc, W., Arpornwichanopd, A., Soottitantawatd, A., Assabumrungratd, S.: Reviews on solid oxide fuel cell technology. Eng J 13(1), 65-83 (2009)

3. SOFC tests and demonstrations: summary. Siemens AG. [Online]. URL. http://www.power generation.siemens.com/products-solutions-services/products-package/fuel-cells/demonstrations/ demonstrations-summary

4. GE Fuel Cells. [Online]. URL. http://www.hydrogen.energy.gov/pdfs/htac_nov14_5_ wellington.pdf

5. Cummins Power Generation. 10kWe SOFC Power System Commercialization Program. [Online]. URL. https://www.netl.doe.gov/File\%20Library/Events/2003/seca/Daniel-Norrick. pdf

6. Somov S.I. Status of researches, developments and practical applications of solid oxide fuel cells. Proc. Solid oxide fuel cells and power installations based on them Conf (2010)

7. Kiselev I.V.: Energy efficiency improving of solid oxide fuel cells and study their application to low power consumers energy supply. Russian federal nuclear center all-russian research institute of experimental physics (2013)

8. Jain, S., Jiang, J., Huang, X., Stevandic, S.: Modeling of fuel-cell-based power supply system for grid interface. IEEE Trans Ind Appl 48(4), 1142-1153 (2012)

9. Loskutov A.B., Sosnina E.N. (and etc): The development of scientific and technical solutions to build hybrid power source based on SOFC and storage system for responsible consumers. Nizhny Novgorod State Technical University, Nizhny Novgorod, Research Rep. GR 114101670042. June 2014

10. Izadian A., Famouri P.: Low cost high efficiency converter for solid oxide fuel cell residential application. Proc. American Science and Technology Conference (2007)

11. Loskutov A.B., Sosnina E.N., Chivenkov A.I., Kryukov E.V.: The development of hybrid power source based on SOFC for distant electricity consumers' power supply. Proc. 2015 IEEE Innovative Smart Grid Technologies - Asia (ISGT ASIA) Conf, pp. 1-6 (2015)

12. Hoppecke batterien [Online]. URL. http://www.hoppecke.com/

13. Chivenkov A.I., Grebenshchikov V.I., Antropov A.P., Mikhailichenko E.A.: Enhanced features of the voltage inverter of renewable energy sources and industrial network systems. Engineering Herald of Don. 24(1) (2013)

Open Access This chapter is licensed under the terms of the Creative Commons Attribution 4.0 International License (http://creativecommons.org/licenses/by/4.0/), which permits use, sharing, adaptation, distribution and reproduction in any medium or format, as long as you give appropriate credit to the original author(s) and the source, provide a link to the Creative Commons license and indicate if changes were made.

The images or other third party material in this chapter are included in the chapter's Creative Commons license, unless indicated otherwise in a credit line to the material. If material is not included in the chapter's Creative Commons license and your intended use is not permitted by statutory regulation or exceeds the permitted use, you will need to obtain permission directly from the copyright holder.

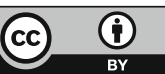

